Please refer to the final version of this text as published in:

Detilleux, C., \& Deschacht, N. (2020, accepted). The causal effect of the number of children on gender-specific labour supply elasticities to the firm. Industrial Relations Journal.

\title{
The causal effect of the number of children on gender-specific labor supply elasticities to the firm
}

\section{Céline Detilleux and Nick Deschacht ${ }^{1}$}

\begin{abstract}
We estimate the effect of the number of children on the female and the male wageelasticity of labor supply to the firm, using instrumental variables estimation in data from the US Current Population Survey (CPS, 2000-2019). Parents' number of children is instrumented with the sex mix of their first two children. We find that the male wage-elasticity of labor supply to the firm significantly increases with the number of children, while the female elasticity is not significantly altered. That is, we find evidence that male labor markets become more competitive with the arrival of children. Our results also show that firms have substantial monopsonistic power and, in line with the monopsony theory of the gender pay gap, that male labor markets are more competitive than female markets.
\end{abstract}

Keywords: Children; Labor Supply; Monopsony power

JEL Classification: J01, J13, J16

${ }^{1}$ Céline Detilleux: KU Leuven, Department of Economics, Warmoesberg 26, 1000 Brussels, Belgium. Nick Deschacht: KU Leuven, Department of Economics, Warmoesberg 26, 1000 Brussels, Belgium. E-mail: celine.detilleux@kuleuven.be 


\section{Introduction}

The effect of parenthood has been extensively investigated in the literature and there is clear evidence that children and family obligations have a substantial impact on the labor market outcomes of men and women (Angelov, Johansson, \& Lindahl, 2016; Angrist \& Evans, 1998; Cools, Markussen, \& Strøm, 2017; Lundberg \& Rose, 2000, 2002). In fact, recent evidence from Kleven, Landais, and Søgaard (2019) suggests that much of the remaining gender pay gap in developed economies is due to children and that the fraction of gender inequality attributable to children has increased dramatically over the past decades. One of the channels that could explain the effects of children on male and female wages, is monopsonistic wage setting power by employers. The explanation of gender pay differences as a result of gender differences in the wage elasticity of labor supply to the firm and of employers in monopsonistic labor markets engaging in wage discrimination, goes back to Joan Robinson (1969) and recent empirical research suggests that gender differences in the elasticity of labor supply go a long way in explaining raw gender pay gaps (Barth \& Dale-Olsen, 2009; Hirsch, Schank, \& Schnabel, 2010; Ransom \& Oaxaca, 2010; Sulis, 2011; Vick, 2017; Webber, 2016). Various factors can cause a difference between male and female firm-specific labor supply elasticities, but children are an important determinant if the childcare obligations for mothers, relative to fathers, limit the number of suitable jobs — for example because these jobs are in a geographic location that is more compatible with childcare or because these jobs have flexible work schedules or other family-friendly practices. However, to the best of our knowledge, there has been no research on the effects of children on male and female labor supply elasticities to the firm.

The aim of this paper is to contribute to the developing literature on imperfect labor markets of men and women by measuring the effect of parenthood on gender 
specific wage-elasticities of labor supply to the firm. In order to identify the effect of the number of children, we adopt an Instrumental Variables (IV) approach because omitted confounders are likely to produce bias in Ordinary Least Squares (OLS) analyses of the effects of children on labor market outcomes. The IV approach allows researchers to uncover the causal effect of the explanatory variable on the dependent variable by inducing changes in the explanatory variable for reasons unrelated to the dependent variable. We exploit the fact that parents exhibit preferences for a mixed sex composition among their children, i.e. parents who have two sons or two daughters are somewhat more likely to have another child (Angrist \& Evans, 1998).

Using the Current Population Survey (CPS), we find that the effect of children on separation rates is negative, once we control for endogeneity. We also find evidence of monopsony since the male and female wage-elasticity of labor supply to the firm are far from infinity: our estimates suggest that women and men are paid, respectively, $34 \%$ and $46 \%$ of their competitive wage. Looking at our variable of interest, we find that female labor markets competitiveness is not significantly altered when the number of children is increased. Alternatively, male labor markets become significantly and substantially more competitive suggesting that firms have less monopsonistic power over men as their number of children increases.

The paper is organized as follows: in the next section, we summarize the literature on parenthood effects and monopsonistic gender wage discrimination. In section 3 we present the empirical specification. Sections 4 and 5 present the dataset and the empirical results and, finally, we draw our conclusions in section 6 .

\section{Previous literature}

Monopsony in the strict sense means that there is only one employer in the labor market, 
so it would be more accurate to define a market with multiple employers as an "oligopsony" or "monopsonistic competition". While the former describes a situation where buyers (employers) enjoy some market power despite competition in the market, the latter is an oligopsony market with free entry, so that employers' profits are driven to zero (Bhaskar, Manning, \& To, 2002). In the "new monopsony" framework, monopsony is more broadly defined as any departure from perfect competition or any situation in which an employer faces an upward sloping labor supply curve so that the firm does not lose all its workers after lowering wages.

Empirically, the degree of monopsonistic power held by employers can be measured by the Pigouvian Exploitation Index (PEI). Under perfect competition, a profitmaximizing firm hires labor at the going market wage up to the point where the wage is equal to the value of the workers' marginal product of labor (MPL). Exercising their monopsony power, employers increase their profits by paying workers at a rate that does not reflect their productivity. The PEI measures the gap between worker's value of the MPL and his/her wage $(w)$ and it can be shown that it is equal to the inverse of the firmlevel labor supply elasticity $\left(\varepsilon_{L w}\right)$ if optimal wage setting is assumed (i.e. wages are set in a profit-maximizing way):

$$
P E I=\frac{M P L-w}{w}=\frac{1}{\varepsilon_{L w}}
$$

In perfect competition, $\varepsilon_{L w}$ tends to infinity and monopsony power (or PEI) to zero. Alternatively, if labor supply to the firm is perfectly inelastic, i.e. when workers work at a firm irrespective of the wage, then $\varepsilon_{L w}$ tends to zero and monopsony power to infinity. Robinson (1969) explained that if an employer is a monopsonist, he can raise his profits by discriminating against workers who are less sensitive to wages. This sort of wage discrimination is referred to as "monopsonistic wage discrimination" (Hirsch, 
2016). The implied wage gap between equally productive workers $a$ and $b$ (having the same MPL), assuming optimal wage setting and if employers can pay both groups different wages, is:

$$
\ln \left(w^{a}\right)-\ln \left(w^{b}\right)=\frac{\varepsilon_{L w}^{a}-\varepsilon_{L w}^{b}}{\varepsilon_{L w}^{b}\left(\varepsilon_{L w}^{a}+1\right)}
$$

Several studies have shown that female labor supply to the firm is less elastic than that of men and, based on equation (2), the predicted gender wage gap ranges between $4 \%$ and 17\% (Barth \& Dale-Olsen, 2009; Booth \& Katic, 2011; Hirsch et al., 2010; Ransom \& Oaxaca, 2010; Sulis, 2011; Vick, 2017; Webber, 2016). Even though these papers have shown evidence for monopsonistic wage discrimination against women, to the best of our knowledge, no studies have attempted to determine the drivers of gender differences in labor supply elasticities. As a point in case, domestic responsibilities may prevent women from following monetary considerations when choosing their employers (Hirsch et al., 2010). They may care more about the job's location, for example because they need a job close to their home or near a nursery school, or about the working hours offered.

Even though not related to monopsony, there is a large literature that reports substantial effects of parenthood on the labor market outcomes of men and women. It is well established that mothers earn lower wages than childless women, both in the US (Anderson, Binder, \& Krause, 2002, 2003; Avellar \& Smock, 2003; Budig, England, et al., 2001; Budig \& Hodges, 2010; Cooke, 2014; Correll, Benard, \& Paik, 2007; Taniguchi, 1999; Waldfogel, 1997, 1998) and in Europe (Davies \& Pierre, 2005; Dotti Sani, 2015; Molina \& Montuenga, 2009; Sigle-Rushton \& Waldfogel, 2007). There is also a growing literature that shows that fathers earn wage premiums compared to childless men, again both in the US (Correll et al., 2007; Glauber, 2008; Hodges \& Budig, 2010; Lundberg \& Rose, 2000, 2002) and in Europe (Koslowski, 2010). Other studies 
have also looked at the effect of parenthood on labor supply (Angrist \& Evans, 1998; Cools et al., 2017; Lundberg \& Rose, 2000, 2002) and showed that women with children work fewer hours, have less prestigious jobs and are less likely to work for pay.

Economists have struggled to estimate the causal effect of children on their mother's labor supply because apparent parenthood effects may result from reverse causality or unobserved heterogeneity if workers who become parents have unobserved characteristics that are correlated with wages. Reverse causality arises when, for example, low-wage earning women are more likely to become mothers. A prominent unobservable fact that complicates the identification of motherhood penalties, is provided by Hakim's (2002) preference theory that some women have a career-oriented lifestyle while other women are more family-oriented. Such lifestyles are hard to measure, while they are likely to be correlated with both fertility and wages. In sum, fertility is likely to be endogenous in equations about labor market outcomes.

One way to separate causation from selection is to use natural experiments and look for variables that induce variation in the number of children for reasons unrelated (except via fertility) to labor market outcomes. Following the work of Angrist and Evans (1998), two variables have often been used in the literature to estimate the effect of children: the sex composition of the first two children and the occurrence of twins at first birth (Cruces \& Galiani, 2007; Maurin \& Moschion, 2009). The validity of the first instrumental variable follows from the phenomenon of parental preferences for mixed sex siblings. Since the sex of the first two children is random (for biological reasons), the sexcomposition of the first two children is widely considered to be a valid instrument for the number of children (as was suggested in the seminal work of Angrist and Evans (1998)). 


\section{Methodology}

We aim at estimating the causal effect of individuals' number of children $(C)$ on the wageelasticity of labor supply to the firm $\left(\varepsilon_{L w}\right)$, our measure of monopsony. Following Manning's (2003) dynamic model of monopsony which views the labor supply of a firm as the result of inflows (recruits) and outflows (separations), we define $\varepsilon_{L w}$ as the difference between the wage-elasticity of recruits $\left(\varepsilon_{R w}\right)$ and separation rate $\left(\varepsilon_{s w}\right): \varepsilon_{L w}=$ $\varepsilon_{R w}-\varepsilon_{s w}$. Based on the Burdett and Mortensen (1998) model, Manning (2003) argues that the wage-elasticity of recruits is equal in absolute terms to the wage-elasticity of separation. Thus, the wage-elasticity of labor supply to the firm can be written as a function of the elasticity of separations only: $\varepsilon_{L w}=-2 \varepsilon_{s w}$.

The wage-elasticity of separation is computed by a probit model for the probability of separation, $s\left(w_{i t}\right)$. The dependent variable measures job separations in period $t$ to either another job or to non-employment in period $t+1$ and the sample consists of all workers with two or more children in period $t$ :

$$
\begin{aligned}
Y_{i t} & =s\left(w_{i t}\right) \\
& =\Phi\left[\beta_{0}+\beta_{1}\left(C_{i t}\right)+\beta_{2} \ln \left(w_{i t}\right)+\beta_{3}\left(\operatorname{sex}_{1, i t}\right)+\beta_{4}\left(\operatorname{sex}_{2, i t}\right)+\beta_{5} X_{i t}\right] \\
& =\Phi\left[I_{i t}\right]
\end{aligned}
$$

where $w_{i t}$ represents the wage of worker $i$ at time $t, C_{i t}$ refers to the number of children of worker $i$ at time period $t, X_{i t}$ is a vector of control variables (age, age ${ }^{2}$, age at first birth, education level, black, hispanic, marital status and industry) and $\operatorname{sex}_{1 i}$ and $\operatorname{sex}_{2 i}$ are indicators, receptively, for the sex of the first and second child of parent $i$.

As mentioned before, the decision to have more children is likely to be endogenous to our outcome of interest. We therefore adopt an Instrumental Variables 
(IV) approach by exploiting the fact that parents exhibit preferences for a mixed sex composition among their children. The first stage equation relating the number of children $\left(C_{i t}\right)$ to sex mix is:

$$
C_{i t}=\alpha_{0}+\alpha_{1}\left(\operatorname{sex}_{1, i t}\right)+\alpha_{2}\left(\operatorname{sex}_{2, i t}\right)+\gamma\left(\text { same } \operatorname{sex}_{i t}\right)+\alpha_{3} X_{i t}+v_{i t}
$$

where $\gamma$ is the first-stage effect of the instrument and $v_{i t}$ is the error term. As an alternative specification, instead of the instrument "same sex", we also use its two components"two boys" and "two girls" - as instruments for the number of children. This is useful because it permits to check for bias from any secular effects of child sex on the separation rate.

This approach uses variation in the sex composition of the first two children as an instrument which induces variation in the total number of children parents eventually end up having. If this instrument was related to labor market outcomes, via channels other than via fertility, there could be a reason for concern because the exclusion restriction assumption of the IV method would be violated. For example, imagine children of different sexes (boy and girl) would argue all the time, whereas same-sex children would not (or vice-versa), then parents of same-sex children might have more time to devote to paid work so that there could be a direct effect of the instrument on labor market outcomes unrelated to the number of children. Although we cannot exclude this possibility, we feel that this effect is likely to be small and therefor poses no serious reason for concern. Another possible violation could in principle result from unobserved variables that are both related to the instrument and labor market outcomes. For example, imagine that more motivated parents do better in the labor market (which is undoubtedly the case) and that more motivated parents are more or less likely to have same-sex children, then again bias would arise. However, since the sex of children is biologically determined in a "random" 
way, this is no reason for concern. Motivated parents are not more or less likely to have same-sex children because parents cannot influence the sex of their children (unless perhaps through sex-specific abortions - but this is unlikely in our sample).

Based on equation (3), the wage-elasticity of labor supply is then estimated as:

$$
\varepsilon_{s w}=\frac{\partial s_{i t}(w)}{\partial w} \frac{w}{s_{i t}(w)}=\beta_{2} \frac{\phi\left(I_{i t}\right)}{\Phi\left(I_{i t}\right)}
$$

The last factor represents the inverse Mills-ratio which depends on $C$. This allows us to estimate the change in the wage-elasticity of the separation rate when the number of children increases.

\section{Data}

The US Current Population Survey (CPS) dataset is used for the period 2000-2019. The CPS is a monthly survey of about 60,000 US households conducted by the Bureau of Labor Statistics. The CPS is a rotating sample, in which households included are interviewed eight times over a sixteen-month period. The longitudinal nature of this dataset allows us to observe separations between workers and firms.

Because the instrumental variable — same sex — is defined only for parents of at least two children, we restrict our analysis to the population of male and female workers with at least two children present in the household. The number of children is defined as the number of children present in the household at the time of the interview (see Appendix A.1). We restrict the sample to employed parents in period $t$ and we define a separation as a move to another job or to non-employment in period $t+1$.

Table 1 presents summary statistics for the covariates, instruments and dependent variables. The average number of children is somewhat higher for men (2.59) than for women (2.48). In our sample of employed individuals with at least two children, $36.8 \%$ 
of women had a third child and the corresponding figure for men is $42.4 \%$. In just over 50 percent of all families, the first two children were of the same sex, which is what could be expected if the sex of a child is random. On average, men are slightly older, the separation rate is higher for women than men (because women more often separate to non-employment), and men have an hourly wage approximately $30 \%$ higher than women.

Table 1: Descriptive statistics, 2000-2019 CPS

\begin{tabular}{|c|c|c|c|}
\hline \multirow{2}{*}{ Variables } & & \multicolumn{2}{|c|}{ Means and (standard deviations) } \\
\hline & & Female sample & Male sample \\
\hline \multirow{2}{*}{\multicolumn{2}{|c|}{ Number of children }} & 2.484 & 2.587 \\
\hline & & $(0.744)$ & $(0.836)$ \\
\hline \multirow{2}{*}{\multicolumn{2}{|c|}{ Third child }} & 0.368 & 0.424 \\
\hline & & $(0.482)$ & $(0.494)$ \\
\hline \multirow{2}{*}{\multicolumn{2}{|c|}{ Boy 1st }} & 0.514 & 0.519 \\
\hline & & $(0.500)$ & $(0.500)$ \\
\hline \multirow{2}{*}{\multicolumn{2}{|c|}{ Boy 2nd }} & 0.508 & 0.514 \\
\hline & & $(0.500)$ & $(0.500)$ \\
\hline \multirow{2}{*}{\multicolumn{2}{|c|}{ Two boys }} & 0.263 & 0.271 \\
\hline & & $(0.440)$ & $(0.444)$ \\
\hline \multirow{2}{*}{\multicolumn{2}{|c|}{ Two girls }} & 0.247 & 0.243 \\
\hline & & $(0.431)$ & $(0.513)$ \\
\hline \multirow{2}{*}{\multicolumn{2}{|c|}{ Same sex }} & 0.509 & 0.513 \\
\hline & & $(0.500)$ & $(0.500)$ \\
\hline \multirow{2}{*}{\multicolumn{2}{|c|}{ Age }} & 36.732 & 37.677 \\
\hline & & $(5.124)$ & $(4.909)$ \\
\hline \multirow{2}{*}{\multicolumn{2}{|c|}{ Age at first birth }} & 24.827 & 26.611 \\
\hline & & $(4.660)$ & $(4.734)$ \\
\hline \multirow[t]{8}{*}{ Education } & High school drop outs & 0.068 & 0.104 \\
\hline & & $(0.252)$ & $(0.305)$ \\
\hline & High school graduates & 0.254 & 0.284 \\
\hline & & $(0.436)$ & $(0.451)$ \\
\hline & Some college & 0.330 & 0.263 \\
\hline & & $(0.470)$ & $(0.440)$ \\
\hline & College graduates & 0.348 & 0.349 \\
\hline & & $(0.476)$ & $(0.477)$ \\
\hline \multirow[t]{6}{*}{ Separation rate } & & 0.041 & 0.030 \\
\hline & & $(0.198)$ & $(0.169)$ \\
\hline & employment & 0.016 & 0.017 \\
\hline & & $(0.125)$ & $(0.128)$ \\
\hline & non-employment & 0.026 & 0.014 \\
\hline & & $(0.159)$ & $(0.116)$ \\
\hline \multirow{2}{*}{\multicolumn{2}{|c|}{ Hourly wage }} & 17.480 & 25.244 \\
\hline & & (13.401) & $(16.712)$ \\
\hline
\end{tabular}




\begin{tabular}{l}
\hline Number of observations \\
NOTE: The samples include women and men, with non missing values of wages, aged \\
21-45 with two or more children except for women whose second child is less than a \\
year old.
\end{tabular}

Table 2 shows the relation between the sex of the first two children and the probability of having a third child in the male and the female samples. The results suggest that women and men with two children of the same sex are much more likely to have a third child. Further analyses also suggest that the sex of the first born has no impact on women's fertility (results not shown).

Table 2: Fraction of families that had another child by sex of children, 2000-2019 CPS

\begin{tabular}{|c|c|c|c|c|}
\hline \multirow[b]{2}{*}{$\begin{array}{l}\text { Sex of the first two } \\
\text { children in families } \\
\text { with two or more } \\
\text { children }\end{array}$} & \multicolumn{2}{|c|}{ All women } & \multicolumn{2}{|c|}{ All men } \\
\hline & $\begin{array}{l}\text { Fraction of } \\
\text { sample }\end{array}$ & $\begin{array}{l}\text { Fraction that } \\
\text { had another } \\
\text { child }\end{array}$ & $\begin{array}{l}\text { Fraction of } \\
\text { sample }\end{array}$ & $\begin{array}{l}\text { Fraction that } \\
\text { had another } \\
\text { child }\end{array}$ \\
\hline Two girls & 0.247 & $\begin{array}{c}0.406 \\
(0.005)\end{array}$ & 0.243 & $\begin{array}{c}0.458 \\
(0.005)\end{array}$ \\
\hline Two boys & 0.263 & $\begin{array}{c}0.395 \\
(0.004)\end{array}$ & 0.271 & $\begin{array}{c}0.451 \\
(0.004)\end{array}$ \\
\hline (1) One girl, one boy & 0.491 & $\begin{array}{c}0.334 \\
(0.003)\end{array}$ & 0.487 & $\begin{array}{c}0.392 \\
(0.003)\end{array}$ \\
\hline (2) Both same sex & 0.509 & $\begin{array}{c}0.400 \\
(0.003)\end{array}$ & 0.513 & $\begin{array}{c}0.454 \\
(0.003)\end{array}$ \\
\hline Difference (1) - (2) & & $\begin{array}{c}-0.066^{* *} \\
(0.004)\end{array}$ & & $\begin{array}{c}-0.062^{* *} \\
(0.005)\end{array}$ \\
\hline
\end{tabular}

NOTE: The samples are the same as in Table 1. (47,962 women and 46,951 men). ${ }^{*} p<0.05$ and ${ }^{* *} p<0.01$

\section{Results}

\subsection{Instrument validity: sex composition and the total number of children}

Our instrumental variable must satisfy the exclusion and relevance assumptions. While we found evidence that the first assumption is satisfied (Appendix B), the relevance 
assumption is tested in Table 3, which presents OLS estimates of the effect of the dummy same sex on the number of children. The estimates show that women with same-sex children, compared to mothers with two children of opposite sex, have 0.09 more children after controlling for the other covariates. The estimates in the male sample are similar, although somewhat smaller. The effect of the dummy is significant at the $1 \%$ significance level and the F-statistics are well above the conventional requirement of 10 for instrument relevance. In other words, the relevance condition is satisfied. The same is true for the components of "same sex": the estimated $\gamma_{1}$ and $\gamma_{2}$ are significantly different from zero at the $1 \%$ significance level. The estimates are, however, slightly different. The estimated effect of "two girls" is larger than the one of "two boys", which suggests a parental preference for boys over girls.

Table 3: OLS estimates of number of children, 2000-2019 CPS

\begin{tabular}{|c|c|c|c|c|c|c|}
\hline \multirow[b]{2}{*}{ Independent variable } & \multicolumn{3}{|c|}{ All women } & \multicolumn{3}{|c|}{ All men } \\
\hline & (1) & $(2)$ & (3) & (1) & (2) & (3) \\
\hline Boy 1st & & $\begin{array}{c}0.0022 \\
(0.0065)\end{array}$ & $\begin{array}{c}0.0124 \\
(0.0092)\end{array}$ & & $\begin{array}{c}0.0023 \\
(0.0075)\end{array}$ & $\begin{array}{c}0.0125 \\
(0.0106)\end{array}$ \\
\hline Boy 2nd & & $\begin{array}{c}0.0111^{*} \\
(0.0065)\end{array}$ & & & $\begin{array}{c}0.0081 \\
(0.0075)\end{array}$ & \\
\hline Same sex & $\begin{array}{c}0.0907^{* * *} \\
(0.0068)\end{array}$ & $\begin{array}{c}0.0925^{* * *} \\
(0.0065)\end{array}$ & & $\begin{array}{c}0.0839^{* * *} \\
(0.0077)\end{array}$ & $\begin{array}{l}0.0849^{* * *} \\
(0.0075)\end{array}$ & \\
\hline Two boys & & & $\begin{array}{c}0.0835^{* * *} \\
(0.0091)\end{array}$ & & & $\begin{array}{c}0.0765^{* * *} \\
(0.0104)\end{array}$ \\
\hline Two girls & & & $\begin{array}{c}0.1038^{* * *} \\
(0.0092)\end{array}$ & & & $\begin{array}{c}0.0964^{* * *} \\
(0.0106)\end{array}$ \\
\hline With other covariates & no & yes & yes & no & yes & yes \\
\hline
\end{tabular}

\subsection{The effect of fertility on male and female wage-elasticities to the firm}

We now present the effect of fertility on the separation rate. Table 4 reports a set of probit 
estimates and two sets of IV-probit estimates using same-sex and the pair of dummies two boys and two girls as instruments. The first three columns give the estimated coefficients of "number of children" and the last three columns the estimated coefficients of " $\log ($ wage)".

Table 4: IV estimates, 2000-2019 CPS

\begin{tabular}{|c|c|c|c|c|c|c|}
\hline \multirow{3}{*}{$\begin{array}{l}\text { Estimation method } \\
\text { Instrument }\end{array}$} & \multicolumn{3}{|c|}{ Effect of children $\left(\beta_{1}\right)$} & \multicolumn{3}{|c|}{ Effect of wage $\left(\beta_{2}\right)$} \\
\hline & Probit & IV-probit & IV-probit & Probit & IV-probit & IV-probit \\
\hline & & Same sex & $\begin{array}{l}\text { Two boys, } \\
\text { two girls }\end{array}$ & & & $\begin{array}{l}\text { Two boys, } \\
\text { two girls }\end{array}$ \\
\hline \multicolumn{7}{|l|}{ Female sample } \\
\hline All sep & $\begin{array}{l}.0493^{* * *} \\
.0166)\end{array}$ & $\begin{array}{l}-0.1282 \\
(0.2714)\end{array}$ & $\begin{array}{l}-0.1185 \\
(0.2682)\end{array}$ & $\begin{array}{c}-0.1034^{* * *} \\
(0.0183)\end{array}$ & $\begin{array}{c}-0.1091^{* * *} \\
(0.0197)\end{array}$ & $\begin{array}{c}-0.1087^{* * *} \\
(0.0197)\end{array}$ \\
\hline Sep $t$ & 0.0080 & 0.0299 & 0.0283 & $-0.0616^{* * *}$ & $-0.0607^{* *}$ & $-0.0606^{* *}$ \\
\hline & 0211) & $(0.3411)$ & $(0.3373)$ & & $(0.0261)$ & $60)$ \\
\hline Sep & $\begin{array}{l}0.0878^{* * *} \\
(0.0217)\end{array}$ & $\begin{array}{l}-0.3203 \\
(0.3495)\end{array}$ & $\begin{array}{l}-0.3197 \\
(0.3495)\end{array}$ & $\begin{array}{l}-0.1407^{* * *} \\
(0.0252)\end{array}$ & $\begin{array}{c}-0.1495^{* * *} \\
(0.0243)\end{array}$ & $\begin{array}{c}-0.1495^{* * *} \\
(0.0243)\end{array}$ \\
\hline & & & & & & \\
\hline$\overline{\text { All }}$ & $\begin{array}{l}0.0375^{* *} \\
(0.0149)\end{array}$ & $\begin{array}{c}-0.5177^{* *} \\
(0.2212)\end{array}$ & $\begin{array}{c}-0.4994^{* *} \\
(0.2204)\end{array}$ & $\begin{array}{l}-0.2018^{* * * *} \\
(0.0205)\end{array}$ & $\begin{array}{c}-0.1974^{* * *} \\
(0.0216)\end{array}$ & $\begin{array}{c}-0.1983^{* * *} \\
(0.0214)\end{array}$ \\
\hline Sep & $\begin{array}{l}0.0547^{* * *} \\
(0.0172)\end{array}$ & -0.3472 & $\begin{array}{l}-0.2988 \\
(0.3064)\end{array}$ & $\begin{array}{c}-0.1660^{* * *} \\
(0.0245)\end{array}$ & $\begin{array}{c}-0.1679^{* * *} \\
(0.0240)\end{array}$ & $\begin{array}{c}-0.1685^{* * *} \\
(0.0240)\end{array}$ \\
\hline Sep & $\begin{array}{c}0.0019 \\
(0.0223)\end{array}$ & $\begin{array}{c}-0.6458^{* *} \\
(0.2745)\end{array}$ & $\begin{array}{c}-0.6967^{* * *} \\
(0.2463)\end{array}$ & $\begin{array}{c}-0.2167^{* * *} \\
(0.0290)\end{array}$ & $\begin{array}{c}-0.2044^{* * *} \\
(0.0326)\end{array}$ & $\begin{array}{c}-0.1995^{* * *} \\
(0.0325)\end{array}$ \\
\hline
\end{tabular}

NOTE: The samples are the same as in Table 1 (47,962 women and 46,951 men). Other covariates in the models are age, age ${ }^{2}$, age at first birth, education level, black, hispanic, marital status and industry. ${ }^{*} p<0.10,{ }^{* *} p<0.05$ and ${ }^{* * *} p<0.01$

The standard probit estimates (no IV) show a positive effect of the number of children and a negative effect of wages on the probability of separation. However, the IV estimates suggest that fertility has no effect on the female separation rate once we control for endogeneity. In the case of men, the effect of the number of children on the separation rate is positive and significant in the probit model, but it turns negative (and significant) once we control for endogeneity.

The estimated effects of log wages on separation rates are negative (as expected) suggesting that the higher is the wage paid, the lower is the probability that the worker separates from the firm. In line with the literature, we also find that the effect is smaller 
in magnitude for women than for men; women are less sensitive to wages than men in their decision to separate from the firm. Decomposing separation rates between separation to employment and non-employment reveals that the effect is larger for separations to non-employment. Table 5 reports the female and male wage elasticities of labor supply to the firm, that were calculated using equation (5). We computed two wage elasticities: (1) holding the number of children constant and (2) increasing the number of children by one unit in the inverse Mills-ratio. The last row gives the difference in these elasticities $\left(\varepsilon_{L w}^{D I F F}\right)$. That is, we test whether the wage-elasticities are statistically different when we increase the number of children by one unit.

Table 5: Wage elasticity of labor supply to the firm, 2000-2019 CPS

\begin{tabular}{lccc}
\hline & $\varepsilon_{L w}^{C}$ & $\varepsilon_{L w}^{C+1}$ & $\varepsilon_{L w}^{D I F F}$ \\
\hline Female sample & $0.5137^{* * *}$ & $0.5385^{* * *}$ & 0.0248 \\
& $(0.0900)$ & $(0.1211)$ & $(0.0545)$ \\
Male sample & $0.8693^{* * *}$ & $1.0502^{* * *}$ & $0.1809^{* * *}$ \\
& $(0.1340)$ & $(0.1081)$ & $(0.0683)$ \\
\hline
\end{tabular}

NOTE: Based on the estimates from the "IV-probit same sex" in Table 4 using equation (5). The other IV estimates in Table 4 produce very similar results. Standard errors are calculated using the delta method. ${ }^{*} \mathrm{p}<.10,{ }^{* *} \mathrm{p}<.05$ and ${ }^{* * *} \mathrm{p}<.01$

The male and female wage elasticities of labor supply to the firm (first column) are far from infinity and significantly different from zero suggesting that employers possess substantial monopsonistic power to set wages. The estimates also suggest that the labor market for men is more competitive; their labor supply to the firm is more wageelastic. The corresponding PEI, which measures the degree of monopsonistic power held by employers, is equal to 1.96 for women and 1.19 for men. This suggests that women and men are paid, respectively, $34 \%$ and $46 \%$ of their competitive wage when optimal wage setting is assumed. The predicted gender wage gap, equation (2), is around $37 \%$.

We find that the female wage elasticity of labor supply to the firm does not change significantly as the number of children increases (Table 5). The male wage-elasticity of 
labor supply, on the other hand, significantly increases when the number of children increases by one unit; the male labor market becomes more competitive as the number of children increases. An additional child leads to a predicted widening of the gender wage gap to $46 \%$ (equation 2). Our results suggest that children contribute to the wage gap by increasing the firm-specific elasticity of males rather than by reducing the elasticity of females.

\subsection{The effect among breadwinners and low-skilled workers}

We now look at the effect of children among breadwinners, who we define as the sole earner or the highest wage in the household. Breadwinners represent respectively $80 \%$ and $45 \%$ of the overall number of men and women with more than two children in our sample. Employers may have more monopsonistic power against those workers since they cannot afford being non-employed for a period of time. This may be even more pronounced with the increase of children in the household. Table 6 and 7, present the results for this restricted sample. We find that the wage-elasticity of labor supply to the firm are drastically lower for breadwinner women than for women in general. The estimates suggest that they only earn approximately $15 \%$ of their competitive wage when optimal wage setting is assumed. The wage-elasticities for breadwinner men are similar to the ones found in Table 5. The effect of children on wage-elasticity is positive but not significant in the sample of breadwinners, in other words, we do not find any effect of children on monopsony power when restricting the sample to breadwinners. 
Table 6: IV estimates, breadwinners 2000-2019 CPS

\begin{tabular}{|c|c|c|c|c|c|c|}
\hline \multirow{3}{*}{$\begin{array}{l}\text { Estimation method } \\
\text { Instrument }\end{array}$} & \multicolumn{3}{|c|}{ Effect of children $\left(\beta_{1}\right)$} & \multicolumn{3}{|c|}{ Effect of wage $\left(\beta_{2}\right)$} \\
\hline & Probit & IV-probit & IV-probit & Probit & IV-probit & IV-probit \\
\hline & & Same sex & $\begin{array}{l}\text { Two boys, } \\
\text { two girls }\end{array}$ & & Same sex & $\begin{array}{l}\text { Two boys, } \\
\text { two girls }\end{array}$ \\
\hline \multicolumn{7}{|l|}{ Female sample } \\
\hline All sep & $\begin{array}{c}0.0199 \\
(0.0300)\end{array}$ & $\begin{array}{l}-0.4265 \\
(0.3695)\end{array}$ & $\begin{array}{l}-0.4257 \\
(0.3584)\end{array}$ & $\begin{array}{l}-0.0289 \\
(0.0337)\end{array}$ & $\begin{array}{l}-0.0368 \\
(0.0326)\end{array}$ & $\begin{array}{l}-0.0367 \\
(0.0326)\end{array}$ \\
\hline Sep to empl. & $\begin{array}{l}-0.0413 \\
(0.0391)\end{array}$ & $\begin{array}{l}-0.4600 \\
(0.4613)\end{array}$ & $\begin{array}{l}-0.4533 \\
(0.4509)\end{array}$ & $\begin{array}{l}-0.0119 \\
(0.0416)\end{array}$ & $\begin{array}{l}-0.0218 \\
(0.0412)\end{array}$ & $\begin{array}{l}-0.0216 \\
(0.0412)\end{array}$ \\
\hline Sep to non-empl. & $\begin{array}{l}0.0910^{* *} \\
(0.0390)\end{array}$ & $\begin{array}{l}-0.2934 \\
(0.5618)\end{array}$ & $\begin{array}{l}-0.3240 \\
(0.5310)\end{array}$ & $\begin{array}{l}-0.0488 \\
(0.0469)\end{array}$ & $\begin{array}{l}-0.0545 \\
(0.0456)\end{array}$ & $\begin{array}{l}-0.0550 \\
(0.0452)\end{array}$ \\
\hline \multicolumn{7}{|l|}{ Male sample } \\
\hline All sep & $\begin{array}{c}0.0202 \\
(0.0170)\end{array}$ & $\begin{array}{l}-0.4100 \\
(0.2739)\end{array}$ & $\begin{array}{l}-0.3808 \\
(0.2746)\end{array}$ & $\begin{array}{l}-0.1890^{* * *} \\
(0.0258)\end{array}$ & $\begin{array}{l}-0.2099^{* * *} \\
(0.0249)\end{array}$ & $\begin{array}{c}-0.2093^{* * *} \\
(0.0254)\end{array}$ \\
\hline Sep to empl. & $\begin{array}{l}0.0403^{* *} \\
(0.0194)\end{array}$ & $\begin{array}{l}-0.2817 \\
(0.3453)\end{array}$ & $\begin{array}{l}-0.2167 \\
(0.3544)\end{array}$ & $\begin{array}{l}-0.1444^{* * *} \\
(0.0309)\end{array}$ & $\begin{array}{l}-0.1633^{* * *} \\
(0.0332)\end{array}$ & $\begin{array}{r}-0.1600^{* * *} \\
(0.0348)\end{array}$ \\
\hline Sep to non-empl. & $\begin{array}{l}-0.0186 \\
(0.0264)\end{array}$ & $\begin{array}{l}-0.5309 \\
(0.3639)\end{array}$ & $\begin{array}{l}-0.6093^{*} \\
(0.3207)\end{array}$ & $\begin{array}{l}-0.2248^{* * *} \\
(0.0372)\end{array}$ & $\begin{array}{l}-0.2429^{* * *} \\
(0.0342)\end{array}$ & $\begin{array}{r}-0.2408^{* * *} \\
(0.0339)\end{array}$ \\
\hline
\end{tabular}

NOTE: The samples are the same as in Table 1 but restricted to breadwinners $(16,381$ women and 35,706 men). Other covariates in the models are age, age ${ }^{2}$, age at first birth education level, black, hispanic and industry. ${ }^{*} p<0.10,{ }^{* *} p<0.05$ and ${ }^{* * *} p<0.01$

Table 7: Wage elasticity of labor supply to the firm, breadwinners 2000-2019 CPS

\begin{tabular}{lccc}
\hline & $\varepsilon_{L w}^{C}$ & $\varepsilon_{L w}^{C+1}$ & $\varepsilon_{L w}^{D I F F}$ \\
\hline Female sample & 0.1712 & 0.1992 & 0.0280 \\
& $(0.1504)$ & $(0.1792)$ & $(0.0373)$ \\
Male sample & $0.9576^{* * *}$ & $1.1105^{* * *}$ & 0.1529 \\
& $(0.1190)$ & $(0.1463)$ & $(0.1065)$ \\
\hline
\end{tabular}

NOTE: Based on the estimates from the "IV-probit same sex" in Table 6 using equation (5). The other IV estimates in Table 6 produce very similar results. Standard errors are calculated using the delta method. ${ }^{*} p<.10,{ }^{* *} p<.05$ and ${ }^{* * *} p<.01$

The consistency of our wage-elasticity of firm-level labor supply estimates relies on the assumption that wages are conditionally exogenous in the separation rate model, equation (3). This assumption does not hold if unobserved factors affect both workers' probabilities of separating and wages. For example, Hirsch and Jahn (2015) explain that worker traits such as ability may lead to bias because high-ability workers who are likely to get higher wages tend to also hold stable jobs. Depew and Sørensen (2013) also indicate 
that high wage workers may have large amounts of non-transferable firm-specific human capital and thus find less outside job offers. Since most of these issues seem to apply especially to high skilled workers, we now restrict the analysis to the sample of high school dropouts and high school graduates. The results are presented in in Tables 8 and 9 and show that our main findings are unaltered. While we cannot rule out that omitted variables bias may still be present and cause some bias in our estimations of firm-specific wage-elasticity, we believe that this problem is less compelling since the purpose of this paper is to look at the effect of the number of children on the wage-elasticity of labor supply.

Table 8: IV estimates, low-skilled 2000-2019 CPS

\begin{tabular}{|c|c|c|c|c|c|c|}
\hline \multirow[b]{2}{*}{$\begin{array}{l}\text { Estimation method } \\
\text { Instrument }\end{array}$} & \multicolumn{3}{|c|}{ Effect of children $\left(\beta_{1}\right)$} & \multicolumn{3}{|c|}{ Effect of wage $\left(\beta_{2}\right)$} \\
\hline & Probit & $\begin{array}{l}\text { IV-probit } \\
\text { Same sex }\end{array}$ & $\begin{array}{l}\text { IV-probit } \\
\text { Two boys, } \\
\text { two girls }\end{array}$ & Probit & $\begin{array}{l}\text { IV-probit } \\
\text { Same sex }\end{array}$ & $\begin{array}{l}\text { IV-probit } \\
\text { Two boys, } \\
\text { two girls }\end{array}$ \\
\hline Female sample & & & & & & \\
\hline All sep & $\begin{array}{c}0.0145 \\
(0.0223)\end{array}$ & $\begin{array}{l}-0.3092 \\
(0.3663)\end{array}$ & $\begin{array}{l}-0.3247 \\
(0.3589)\end{array}$ & $\begin{array}{l}-0.0675^{* * *} \\
(0.0240)\end{array}$ & $\begin{array}{l}-0.0761^{* * *} \\
(0.0247)\end{array}$ & $\begin{array}{c}-0.0762^{* * *} \\
(0.0245)\end{array}$ \\
\hline Sep to empl. & $\begin{array}{l}-0.0108 \\
(0.0278)\end{array}$ & $\begin{array}{l}-0.4414 \\
(0.4290)\end{array}$ & $\begin{array}{l}-0.5193 \\
(0.4020)\end{array}$ & $\begin{array}{l}-0.0358 \\
(0.0294)\end{array}$ & $\begin{array}{l}-0.0488 \\
(0.0302)\end{array}$ & $\begin{array}{l}-0.0506^{*} \\
(0.0293)\end{array}$ \\
\hline Sep to non-empl. & $\begin{array}{c}0.0429 \\
(0.0298)\end{array}$ & $\begin{array}{l}-0.0356 \\
(0.5569)\end{array}$ & $\begin{array}{l}-0.0353 \\
(0.5477)\end{array}$ & $\begin{array}{l}-0.0987^{* * *} \\
(0.0335)\end{array}$ & $\begin{array}{l}-0.1011^{* * *} \\
(0.0368)\end{array}$ & $\begin{array}{c}-0.1012^{* * *} \\
(0.0367)\end{array}$ \\
\hline Male sa & & & & & & \\
\hline All sep & $\begin{array}{l}0.0607^{* * *} \\
(0.0206)\end{array}$ & $\begin{array}{c}-0.6439^{* * *} \\
(0.1974)\end{array}$ & $\begin{array}{c}-0.6671^{* * *} \\
(0.1751)\end{array}$ & $\begin{array}{l}-0.2339^{* * *} \\
(0.0300)\end{array}$ & $\begin{array}{l}-0.2447^{* * *} \\
(0.0281)\end{array}$ & $\begin{array}{r}-0.2432^{* * *} \\
(0.0277)\end{array}$ \\
\hline Sep to empl. & $\begin{array}{l}0.0889^{* * *} \\
(0.0246)\end{array}$ & $\begin{array}{l}-0.3545 \\
(0.3457)\end{array}$ & $\begin{array}{l}-0.3070 \\
(0.3336)\end{array}$ & $\begin{array}{l}-0.1962^{* * *} \\
(0.0374)\end{array}$ & $\begin{array}{l}-0.2139^{* * *} \\
(0.0353)\end{array}$ & $\begin{array}{r}-0.2133^{* * *} \\
(0.0360)\end{array}$ \\
\hline Sep to non-empl. & $\begin{array}{c}0.0127 \\
(0.0289)\end{array}$ & $\begin{array}{c}-0.8046^{* * *} \\
(0.1826)\end{array}$ & $\begin{array}{c}-0.8740^{* * *} \\
(0.1382)\end{array}$ & $\begin{array}{l}-0.2402^{* * *} \\
(0.0397)\end{array}$ & $\begin{array}{l}-0.2429^{* * *} \\
(0.0357)\end{array}$ & $\begin{array}{c}-0.2338^{* * *} \\
(0.0337)\end{array}$ \\
\hline
\end{tabular}

NOTE: The samples are the same as in Table 1 but restricted to low-skilled workers $\left(14,931\right.$ women and 17,866 men). Other covariates in the models are age, age ${ }^{2}$, age at first birth, black, hispanic, marital status, and industry. ${ }^{*} p<0.10,{ }^{* *} p<0.05$ and ${ }^{* * *} p<0.01$ 
Table 9: Wage elasticity of labor supply to the firm, low-skilled 2000-2019 CPS

\begin{tabular}{lccc}
\hline & $\varepsilon_{L w}^{C}$ & $\varepsilon_{L w}^{C+1}$ & $\varepsilon_{L w}^{D I F F}$ \\
\hline Female sample & $0.4547^{* * *}$ & $0.5055^{* * *}$ & 0.0508 \\
& $(0.1448)$ & $(0.1881)$ & $(0.0668)$ \\
Male sample & $0.9693^{* * *}$ & $1.2434^{* * *}$ & 0.2741 \\
& $(0.1635)$ & $(0.1454)$ & $(0.0743)$ \\
\hline
\end{tabular}

NOTE: Based on the estimates from the "IV-probit same sex" in Table 8 using equation (5). The other IV estimates in Table 8 produce very similar results. Standard errors are calculated using the delta method. ${ }^{*} p<.10,{ }^{* *} p<.05$ and ${ }^{* * *} p<.01$

\section{Conclusion and discussion}

Over the past decades, economists have refuted the generally considered perfectly competitive model for labor markets and have argued that firms possess some monopsonistic power. This paper aims at understanding the drivers of workers' upward labor supply curves; more precisely, we determine the effect of the number of children on firm-level labor supply elasticities of men and women. Our IV-probit estimates that exploit the fertility consequences of sibling sex composition contradict the standard estimates, that do not control for endogeneity, that falsely suggest that children increase male and female separation rates. Indeed, the effect reduces drastically and even turns negative. The standard estimates appear to exaggerate the causal effect of children and this suggests that the relation between the number of children and separation rates is affected by confounder variables. We can only speculate about the nature of these confounders, but the 'common unobservables' (e.g. motivation, 'ability' or lifestyle preferences) may go a long way in explaining these results. For example, if workers who are more 'career oriented' get less children and if these career-oriented workers are less likely to separate (in particular to non-employment) then the type of upward bias arises which we find in the probit estimates.

In all specifications, the effect of wages on separation rates is, as expected, negative and 
significant. In line with the literature (Barth \& Dale-Olsen, 2009; Hirsch et al., 2010; Ransom \& Oaxaca, 2010; Sulis, 2011; Vick, 2017; Webber, 2016), our findings show that wage-elasticities are far from infinity and that firms have more monopsonistic power over women. Indeed, we find that women are paid 34\% of their competitive wage when optimal wage setting is assumed while the corresponding figure for men is $46 \%$. The gender pay gap implied by this gender difference in monopsony power is around $37 \%$. Our main finding is that male labor markets become significantly more competitive in response to an increase in the number of children while the female wage-elasticity of labor supply to the firm does not significantly change as the number of children increases. In other words, men behave in a more competitive way in the labor market as their number of children increases. The results remain unaltered when we restrict the sample to breadwinners and low-skilled individuals with two or more children. Yet, we find that the wage-elasticity of labor supply to the firms is drastically lower for breadwinner women than for women in general. The effect of wages on separations is close to zero and not significant in our sample of breadwinner women. This suggest that it is hard for breadwinner mothers to quit their jobs.

The fact that male labor markets become more competitive as the number of children increases, could be related to the different roles men and women continue to assume in the family. The traditional role division in the family was often summarized by stating that children cost time and money (Craig, 2007; McDonald, 2006) - and that mothers provide the time and fathers the money. Our findings that the male elasticity increases with the number of children and the overall female elasticities are lower for women than for men, are in line with what can be expected from this role division in the family. As money becomes relatively scarcer within the family with the arrival of children, fathers appear to switch to more competitive types of behavior. The main source of monopsony 
power of employers is thought to reside in frictions in the labor market, such as mobility costs (Bhaskar, Manning \& To, 2002), preferences for a particular employer or ignorance about outside vacancies (Stigler, 1962; Stiglitz, 1989), which hinder the mobility of workers to switch employers in search for higher wages. One possibility is that men become less attached or loyal to their current employer with the arrival of children, but this is speculative and further research is needed to clarify which of these channels are affected by fertility. In this role division view of the family, it is somewhat remarkable that we do not find a significant (negative) effect of the number of children on the female elasticity. One possible explanation could be that women anticipate motherhood (Bass, 2015; Blau \& Khan, 2017), that women choose to work for more "mom-friendly companies" and thus are less sensitive to wages even before the arrival of a new child. However, this raises the question as to why men would not anticipate fatherhood. Another explanation could be that our sample is restricted to parents with at least two children, which is a limitation of our research that was unavoidable given our IV identification strategy. Although the same sex instrument provides valuable and credible effect estimates, its informational values is limited to fertility effects at the intensive margins. We cannot estimate the effect of fertility on labor supply at the extensive margin. The effects of a first child might be different from getting additional children beyond a second child and thus we might be missing an important dimension of child-rearing. Another limitation of the paper is that, even if employers have some monopsonistic power, our evidence cannot tell to what extent they exploit this monopsonistic power. The purpose of the paper is to determine how childbearing affects gender differences in wages elasticities but further research is needed to clarify to what extent wages are pushed below the competitive level and how this interacts with childbearing. 


\section{Acknowledgements}

We thank Dieter Verhaest, Sunčica Vujić, the editor and two anonymous reviewers for their helpful comments and suggestions on earlier versions of this paper. We are also grateful to seminar participants at the 2019 Belgian day for Labour Economists in Maastricht for their valuable comments and suggestions.

\section{References}

Anderson, D. J., Binder, M., \& Krause, K. (2002). The motherhood wage penalty: Which mothers pay it and why? American Economic Review, 92(2), 354-358.

Anderson, D. J., Binder, M., \& Krause, K. (2003). The motherhood wage penalty revisited: Experience, heterogeneity, work effort, and work-schedule flexibility. ILR Review, 56(2), 273-294.

Angelov, N., Johansson, P., \& Lindahl, E. (2016). Parenthood and the gender gap in pay. Journal of Labor Economics, 34(3), 545-579.

Angrist, J. D., \& Evans, W. N. (1998). Children and their parents' labor supply: Evidence from exogenous variation in family size. American Economic Review, $88(3), 450-77$.

Avellar, S., \& Smock, P. J. (2003). Has the price of motherhood declined over time? a cross-cohort comparison of the motherhood wage penalty. Journal of Marriage and Family, 65(3), 597-607.

Bass, B. C. (2015). Preparing for parenthood? Gender, aspirations, and the reproduction of labor market inequality. Gender \& Society, 29(3), 362-385.

Barth, E., \& Dale-Olsen, H. (2009). Monopsonistic discrimination, worker turnover, and the gender wage gap. Labour Economics, 16(5), 589-597.

Bhaskar, V., Manning, A., \& To, T. (2002). Oligopsony and monopsonistic competition in labor markets. Journal of Economic Perspectives, 16(2), 155-174.

Blau, F. D., \& Kahn, L. M. (2017). The gender wage gap: Extent, trends, and explanations. Journal of Economic Literature, 55(3), 789-865.

Booth, A. L., \& Katic, P. (2011). Estimating the wage elasticity of labor supply to a firm: What evidence is there for monopsony? Economic Record, 87(278), 359369.

Budig, M. J., England, P., et al. (2001). The wage penalty for motherhood. American Sociological Review, 66(2), 204-225.

Budig, M. J., \& Hodges, M. J. (2010). Differences in disadvantage: Variation in the motherhood penalty across white women's earnings distribution. American Sociological Review, 75(5), 705-728.

Burdett, K., \& Mortensen, D. T. (1998). Wage differentials, employer size, and unemployment. International Economic Review, 257-273.

Cooke, L. P. (2014). Gendered parenthood penalties and premiums across the earnings distribution in australia, the united kingdom, and the united states. European Sociological Review, 30(3), 360-372. 
Cools, S., Markussen, S., \& Strøm, M. (2017). Children and careers: How family size affects parents' labor market outcomes in the long run. Demography, 54(5), 1773-1793.

Correll, S. J., Benard, S., \& Paik, I. (2007). Getting a job: Is there a motherhood penalty? American Journal of Sociology, 112(5), 1297-1338.

Craig, L. (2007). Contemporary motherhood: The impact of children on adult time. Aldershot, UK: Ashgate.

Cruces, G., \& Galiani, S. (2007). Fertility and female labor supply in latin america: New causal evidence. Labour Economics, 14(3), 565-573.

Davies, R., \& Pierre, G. (2005). The family gap in pay in europe: A cross-country study. Labour Economics, 12(4), 469-486.

Depew, B., \& Sørensen, T. A. (2013). The elasticity of labor supply to the firm over the business cycle. Labour Economics, 24, 196-204.

Dotti Sani, G. M. (2015). Within-couple inequality in earnings and the relative motherhood penalty. a cross-national study of european countries. European Sociological Review, 31(6), 667-682.

Glauber, R. (2008). Race and gender in families and at work: The fatherhood wage premium. Gender \& Society, 22(1), 8-30.

Hakim, C. (2002). Lifestyle preferences as determinants of women's differentiated labor market careers. Work and Occupations, 29(4), 428-459.

Hirsch, B. (2016). Gender wage discrimination: Does the extent of competition in labor markets explain why female workers are paid less than men? IZA World of Labor(310).

Hirsch, B., \& Jahn, E. J. (2015). Is there monopsonistic discrimination against immigrants? ILR Review, 68(3), 501-528.

Hirsch, B., Schank, T., \& Schnabel, C. (2010). Differences in labor supply to monopsonistic firms and the gender pay gap: An empirical analysis using linked employer-employee data from germany. Journal of Labor Economics, 28(2), 291-330.

Hodges, M. J., \& Budig, M. J. (2010). Who gets the daddy bonus? organizational hegemonic masculinity and the impact of fatherhood on earnings. Gender \& Society, 24(6), 717-745.

Kleven, H., Landais, C., \& Søgaard, J. E. (2019). Children and gender inequality: Evidence from denmark. American Economic Journal: Applied Economics, 11(4), 181-209.

Koslowski, A. S. (2010). Working fathers in europe: Earning and caring. European Sociological Review, 27(2), 230-245.

Lundberg, S., \& Rose, E. (2000). Parenthood and the earnings of married men and women. Labour Economics, 7(6), 689-710.

Lundberg, S., \& Rose, E. (2002). The effects of sons and daughters on men's labor supply and wages. Review of Economics and Statistics, 84(2), 251-268.

McDonald, P. (2006). Low fertility and the state: The efficacy of policy. Population and Development Review, 32, 485 - 510.

Manning, A. (2003). Monopsony in motion: Imperfect competition in labor markets. Princeton University Press.

Maurin, E., \& Moschion, J. (2009). The social multiplier and labor market participation of mothers. American Economic Journal: Applied Economics, 1(1), 251-72.

Molina, J. A., \& Montuenga, V. M. (2009). The motherhood wage penalty in spain. Journal of Family and Economic Issues, 30(3), 237-251. 
Ransom, M. R., \& Oaxaca, R. L. (2010). New market power models and sex differences in pay. Journal of Labor Economics, 28(2), 267-289.

Robinson, J. (1969). The economics of imperfect competition. Springer.

Sigle-Rushton, W., \& Waldfogel, J. (2007). Motherhood and women's earnings in anglo-american, continental european, and nordic countries. Feminist Economics, 13(2), 55-91.

Stigler, G. J. (1962). Information in the labor market. Journal of Political Economy, 70 (5, Part 2), 94-105.

Stiglitz, J. E. (1989). Imperfect information in the product market. Handbook of Industrial Organization, 1 , 769-847.

Sulis, G. (2011). What can monopsony explain of the gender wage differential in italy? International Journal of Manpower, 32(4), 446-470.

Taniguchi, H. (1999). The timing of childbearing and women's wages. Journal of Marriage and the Family, 1008-1019.

Vick, B. (2017). Measuring links between labor monopsony and the gender pay gap in brazil. IZA Journal of Development and Migration, 7(1), 10.

Waldfogel, J. (1997). The effect of children on women's wages. American Sociological Review, 209-217.

Waldfogel, J. (1998). Understanding the" family gap" in pay for women with children. Journal of Economic Perspectives, 12(1), 137-156.

Webber, D. A. (2016). Firm-level monopsony and the gender pay gap. Industrial Relations, 55(2), 323-345. 
Online appendices:

\section{A Variables}

\section{A.1 Linking information on children and parents}

Children are matched to mothers and fathers using the family interrelationships variables.

These codes show how each individual in the household is related to the person identified as the householder. In most cases, the mother/child match is straightforward. For example, if a woman in our sample is designated as the householder or the spouse of another householder, we attached all people in the household labeled as "child" in the primary relationship code to this woman. In households with multiple families, the match is more complicated. We thereafter restrict the analysis to householder and their spouse (if present).

The number of children attached to the mother is sometimes smaller than the number of reported births because not all children live with their mother, or because of the death of a child. Likewise, the number of children matched to a mother may exceed the number of reported births because we do not identify adopted children or stepchildren. For $99 \%$ of mothers and $99 \%$ of fathers in our sample, the self-reports of children ever born was the same as our count of children born. 


\section{A.2 Variables definition}

Table A.1: Definition of variables in 2000-2019 CPS

\begin{tabular}{|c|c|}
\hline Variable & Description \\
\hline Third child & $\begin{array}{l}=1 \text { if individual has more than } 2 \text { children, }=0 \text { the } \\
\text { individual has exactly } 2 \text { children }\end{array}$ \\
\hline sex 1 & $=1$ if first child is a boy, $=0$ otherwise \\
\hline $\operatorname{sex} 2$ & $=1$ if second child is a boy, $=0$ otherwise \\
\hline same sex & $\begin{array}{l}=1 \text { if first two children are the same sex, }=0 \\
\text { otherwise }\end{array}$ \\
\hline two boys & $=1$ if first two children are boys, $=0$ otherwise \\
\hline two girls & $=1$ if first two children are girls, $=0$ otherwise \\
\hline Age at first birth & parent's age in years when first child was born \\
\hline Marital status & $\begin{array}{l}=1 \text { if individual is married } \\
=2 \text { if individual is separated } \\
=3 \text { if individual is single }\end{array}$ \\
\hline Education & $\begin{array}{l}=\text { "high-school drop-out" if individual has } 11 \text { or } \\
\text { fewer years of education completed } \\
=\text { "high-school graduate" if individual has } 12 \\
\text { years of education completed } \\
=\text { "some college" if individual has } 13-15 \text { years of } \\
\text { education completed } \\
=\text { "college graduate" if individual has } 16 \text { of more } \\
\text { years of education completed }\end{array}$ \\
\hline Separation to employment & $\begin{array}{l}=1 \text { if individual is in continuous employment } \\
\text { between time } t \text { and } t+1 \text { and has a new job at time } \\
t+1,=0 \text { otherwise }\end{array}$ \\
\hline Separation to non-employment & $\begin{array}{l}=1 \text { if individual is employed in time } t \text { and non- } \\
\text { employed } t+1,=0 \text { otherwise }\end{array}$ \\
\hline Hourly wage & hourly wage at the time of the survey \\
\hline Breadwinner & $\begin{array}{l}=1 \text { if individual is the primary or sole income } \\
\text { earner in a household at time } t,=0 \text { otherwise }\end{array}$ \\
\hline
\end{tabular}




\section{B IV assumptions}

Our instrumental variable must meet the exclusion restriction and the relevance assumption. To understand those two assumption, recall that the probit model, equation (3), relies on the unobserved true model:

$$
Y_{i t}^{*}=\delta_{0}+\delta_{1}\left(C_{i t}\right)+\delta_{2} \ln \left(w_{i t}\right)+\delta_{3}\left(\operatorname{sex}_{1, i t}\right)+\delta_{4}\left(\operatorname{sex}_{2, i t}\right)+\delta_{5} X_{i t}+\zeta_{i t}
$$

where $\zeta_{i t}$ is an error term. Then the exclusion restriction and the relevance conditions for the instrument "same sex" can be written as:

$$
\begin{array}{r}
\mathbb{E}\left(\zeta_{i t} \mid \text { same sex } X\right)=0 \\
\operatorname{cov}(C ; \text { same sex }) \neq 0
\end{array}
$$

That is, our instrument must be exogenous in equation (A.1) and it must be partially correlated with our endogenous variable once the other exogenous variables have been netted out. The same conditions apply for the instruments "two boys" and "two girls". While the first condition (exogeneity) can generally not be tested, the second condition (relevance) is tested by looking at the significance of $\gamma$ in the first stage equation (4). Since sex mix is virtually randomly assigned for biological reasons, a dummy for whether the sex of the second child matches the sex of the first child is very likely to satisfy the first condition. A simple check of this claim is implemented in Table B.1 which presents the covariates mean differences between mothers and fathers with different-sex children ( The two-sided t-tests indicate that there are almost no differences in the observable background characteristics. Only the age and the agriculture industry difference is significant at the $5 \%$ level, but the difference is small and this could be a false positive (type I error) given the large number of tests presented in the table. Thus, the sex mix of the two first children seems to be unrelated to observable characteristics. 
Table B.1: Mean (standard deviation), 2000-2019 CPS

\begin{tabular}{|c|c|c|c|c|c|c|c|}
\hline & \multicolumn{3}{|c|}{ All women } & \multicolumn{3}{|c|}{ All men } \\
\hline & & $\begin{array}{l}\text { Same } \\
\text { sex }=0\end{array}$ & $\begin{array}{l}\text { Same } \\
\text { sex }=1\end{array}$ & T-test & $\begin{array}{l}\text { Same } \\
\text { sex }=0\end{array}$ & $\begin{array}{l}\text { Same } \\
\text { sex }=1\end{array}$ & T-test \\
\hline \multirow[t]{2}{*}{ Age } & & 36.672 & 36.789 & $-2.500^{*}$ & 37.631 & 37.720 & $-1.972^{*}$ \\
\hline & & $(5.128)$ & $(5.120)$ & $(5.124)$ & $(4.914)$ & $(4.904)$ & $(4.909)$ \\
\hline \multirow{6}{*}{$\begin{array}{l}\text { Marital } \\
\text { status }\end{array}$} & Married & 0.788 & 0.790 & -0.643 & 0.953 & 0.950 & 1.316 \\
\hline & & $(0.409)$ & $(0.407)$ & $(0.408)$ & $(0.212)$ & $(0.217)$ & $(0.215)$ \\
\hline & Separated & 0.136 & 0.134 & 0.634 & 0.029 & 0.033 & $-2.077^{*}$ \\
\hline & & $(0.343)$ & $(0.341)$ & $(0.342)$ & $(0.169)$ & $(0.178)$ & $(0.173)$ \\
\hline & Single & 0.076 & 0.076 & 0.172 & 0.018 & 0.017 & 0.595 \\
\hline & & $(0.266)$ & $(0.265)$ & $(0.265)$ & $(0.132)$ & $(0.129)$ & $(0.131)$ \\
\hline \multirow[t]{2}{*}{ Black } & & 0.107 & 0.110 & -1.019 & 0.060 & 0.067 & $-3.149^{* *}$ \\
\hline & & $(0.309)$ & $(0.313)$ & $(0.311)$ & $(0.238)$ & $(0.250)$ & $(0.244)$ \\
\hline \multirow[t]{2}{*}{ Hispan } & & 0.136 & 0.132 & 1.272 & 0.165 & 0.166 & -0.210 \\
\hline & & $(0.343)$ & $(0.339)$ & $(0.341)$ & $(0.371)$ & $(0.372)$ & $(0.371)$ \\
\hline \multirow[t]{8}{*}{ Education } & High school drop outs & 0.070 & 0.067 & 1.382 & 0.102 & 0.106 & -1.685 \\
\hline & & $(0.255)$ & $(0.250)$ & $(0.252)$ & $(0.302)$ & $(0.308)$ & $(0.305)$ \\
\hline & High school graduates & 0.252 & 0.257 & -1.063 & 0.285 & 0.284 & 0.397 \\
\hline & & $(0.434)$ & $(0.437)$ & $(0.436)$ & $(0.452)$ & $(0.451)$ & $(0.451)$ \\
\hline & Some college & 0.332 & 0.327 & 1.021 & 0.262 & 0.264 & -0.532 \\
\hline & & $(0.471)$ & $(0.469)$ & $(0.470)$ & $(0.440)$ & $(0.441)$ & $(0.440)$ \\
\hline & College graduates & 0.346 & 0.349 & -0.768 & 0.351 & 0.346 & 1.195 \\
\hline & & $(0.476)$ & $(0.477)$ & $(0.476)$ & $(0.477)$ & $(0.476)$ & $(0.477)$ \\
\hline \multirow[t]{24}{*}{ Industry } & Agriculture, forestry; & 0.011 & 0.009 & $2.671^{* *}$ & 0.044 & 0.038 & $3.243^{* *}$ \\
\hline & mining and fisheries & $(0.105)$ & $(0.093)$ & $(0.099)$ & $(0.206)$ & $(0.192)$ & $(0.199)$ \\
\hline & Construction & 0.015 & 0.151 & -0.002 & 0.189 & 0.187 & 0.407 \\
\hline & & $(0.121)$ & $(0.122)$ & $(0.122)$ & $(0.391)$ & $(0.390)$ & $(0.391)$ \\
\hline & Manufacturing & 0.080 & 0.083 & -0.974 & 0.103 & 0.106 & -1.066 \\
\hline & & $(0.272)$ & $(0.276)$ & $(0.274)$ & $(0.304)$ & $(0.308)$ & $(0.306)$ \\
\hline & Transportation, & 0.037 & 0.039 & -1.228 & 0.050 & 0.051 & -0.149 \\
\hline & $\begin{array}{l}\text { communication and } \\
\text { other public utilities }\end{array}$ & $(0.188)$ & $(0.194)$ & $(0.191)$ & $(0.219)$ & $(0.219)$ & $(0.219)$ \\
\hline & Wholesale trade & 0.020 & 0.020 & 0.639 & 0.112 & 0.117 & $-1.784^{*}$ \\
\hline & & $(0.142)$ & $(0.139)$ & $(0.140)$ & $(0.315)$ & $(0.322)$ & $(0.319)$ \\
\hline & Retail trade & 0.144 & 0.141 & 0.989 & 0.062 & 0.059 & 1.227 \\
\hline & & $(0.351)$ & $(0.348)$ & $(0.350)$ & $(0.241)$ & $(0.236)$ & $(0.024)$ \\
\hline & Finance, insurance and & 0.085 & 0.082 & 1.373 & 0.076 & 0.079 & -1.098 \\
\hline & real estate & $(0.279)$ & $(0.274)$ & $(0.276)$ & $(0.265)$ & $(0.269)$ & $(0.267)$ \\
\hline & Business and repair & 0.049 & 0.049 & -0.107 & 0.012 & 0.012 & 0.721 \\
\hline & services & $(0.216)$ & $(0.217)$ & $(0.217)$ & $(0.111)$ & $(0.107)$ & $(0.109)$ \\
\hline & Personal services & 0.034 & 0.034 & -0.088 & 0.012 & 0.009 & 2.882 \\
\hline & & $(0.181)$ & $(0.181)$ & $(0.181)$ & $(0.110)$ & $(0.099)$ & $(0.104)$ \\
\hline & Entrainment and & 0.015 & 0.014 & 1.025 & 0.151 & 0.151 & -0.028 \\
\hline & recreation services & $(0.120)$ & $(0.116)$ & $(0.118)$ & $(0.358)$ & $(0.358)$ & $(0.358)$ \\
\hline & Professional and related & 0.462 & 0.469 & -1.531 & 0.062 & 0.060 & 0.483 \\
\hline & services & $(0.499)$ & $(0.499)$ & $(0.499)$ & $(0.240)$ & $(0.238)$ & $(0.239)$ \\
\hline & Public administration & 0.047 & 0.046 & 0.619 & 0.000 & 0.000 & 1.027 \\
\hline & & $(0.211)$ & $(0.209)$ & $(0.210)$ & $(0.007)$ & $(0.000)$ & $(0.005)$ \\
\hline \multirow{2}{*}{\multicolumn{2}{|c|}{ Hourly wage }} & 2.608 & 2.605 & 0.455 & 3.027 & 3.026 & 0.085 \\
\hline & & $(0.743)$ & $(0.740)$ & $(0.742)$ & $(0.662)$ & $(0.658)$ & $(0.660)$ \\
\hline
\end{tabular}

NOTE: The samples are the same as in Table 1 (47,962 women and 46,951 men).

${ }^{*} p<.05$ and ${ }^{* *} p<.01$ 